Tropical Journal of Pharmaceutical Research April 2016; 15 (4): 679-685

ISSN: $1596-5996$ (print); 1596-9827 (electronic)

(C) Pharmacotherapy Group, Faculty of Pharmacy, University of Benin, Benin City, 300001 Nigeria.

All rights reserved.

Available online at http://www.tjpr.org

Original Research Article

http://dx.doi.org/10.4314/tjpr.v15i4.2

\title{
Characterization of silver nanoparticles prepared by wet chemical method and their antibacterial and cytotoxicity activities
}

\author{
Manal A Awad ${ }^{1}$, Awatif A Hendi ${ }^{2}$, Khalid MO Ortashi ${ }^{3}$, Reem A Alotaibi ${ }^{4}$ and \\ Maha Sh Sharafeldin ${ }^{5}$ \\ ${ }^{1}$ King Abdullah Institute for Nanotechnology, ${ }^{2}$ Department of Physics, Faculty of Science, ${ }^{3}$ Department of Chemical \\ Engineering, King Saud University, ${ }^{4}$ Faculty of Science and Humanitarian Studies, Prince Sattam Bin Abdul Aziz University. \\ Riyadh, Saudi Arabia, ${ }^{5}$ Faculty of Agriculture- Food Science and Technology, University of Khartoum, Khartoum, Sudan
}

*For correspondence: Email: mawad@ksu.edu.sa, ahindi@ksu.edu.sa

\begin{abstract}
Purpose: To investigate the efficiency of silver nanoparticles synthesized by wet chemical method, and evaluate their antibacterial and anti-cancer activities.

Methods: Wet chemical method was used to synthesize silver nanoparticles (AgNPs) from silver nitrate, trisodium citrate dehydrate $\left(\mathrm{C}_{6} \mathrm{H}_{5} \mathrm{O}_{7} \mathrm{Na}_{3} .2 \mathrm{H}_{2} \mathrm{O}\right)$ and sodium borohydride $\left(\mathrm{NaBH}_{4}\right)$ as reducing agent. The AgNPs and the reaction process were characterized by UV-visible spectrometry, zetasizer, transmission electron microscopy (TEM) and scanning electron microscopy (SEM) equipped with energy dispersive spectroscopy (EDS). The antibacterial and cytotoxic effects of the synthesized nanoparticles were investigated by agar diffusion method and MTT assay respectively.

Results: The silver nanoparticles formed were spherical in shape with mean size of $10.3 \mathrm{~nm}$. The results showed good antibacterial properties, killing both Gram-positive and Gram-negative bacteria, and its aqueous suspension displayed cytotoxic activity against colon adenocarcinoma (HCT-116) cell line.

Conclusion: The findings indicate that silver nanoparticles synthesized by wet chemical method demonstrate good cytotoxic activity in colon adenocarcinoma (HCT-116) cell lines and strong antibacterial activity against various strains of bacteria.
\end{abstract}

Keywords: Wet chemical, Silver nanoparticles, Characterization, Diffusion method, Antibacterial, Cytotoxic activity

Tropical Journal of Pharmaceutical Research is indexed by Science Citation Index (SciSearch), Scopus, International Pharmaceutical Abstract, Chemical Abstracts, Embase, Index Copernicus, EBSCO, African Index Medicus, JournalSeek, Journal Citation Reports/Science Edition, Directory of Open Access Journals (DOAJ), African Journal Online, Bioline International, Open-J-Gate and Pharmacy Abstracts

\section{INTRODUCTION}

Nanotechnology is probably one of the fastest developing sciences over the last few years. It is an interdisciplinary science that connects knowledge of biology, chemistry, physics, material science, engineering, pharmacology, and medicine. The products of nanotechnology, nanoparticles, have a size $<100 \mathrm{~nm}$ and, due to their small size, have very high bioactivity [1].

Metal nanoparticles can be prepared and stabilized by physical and chemical methods [2]. Numerous approaches had been used to prepare silver nanoparticles (AgNPs). Examples of physical technique to prepare AgNPs are photochemical synthesis, laser ablation, phase 
transfer processes, microemulsion, microwave treatment [3], which had been used for preparation in both solution and solid phases of silver nanoparticles. Chemical methods are widely used to produce nanostructured materials due to their straight forward nature and their potential to produce large quantities of the final product. The particle sizes of the nanoparticles can be controlled by systematically adjusting the reaction parameters, such as time, temperature [4], and the concentration of reagents and stabilizing agents [5]. A variety of chemical approaches have also been utilized to produce silver nanoparticles with different size distribution and different shapes [6].

Unique interactions with bacteria and virus have been demonstrated by silver nanoparticles of certain size ranges and shapes [7]. The antimicrobial properties of silver nano have been applied widely to biomedical devices, water purification, clothing, cosmetics and other numerous household products [8]. Cancer is an abnormal type of tissue growth in which the cells exhibit an uncontrolled division, relatively in an autonomous fashion, leading to a progressive increase in the number of dividing cell.

There is increasing demands for anticancer therapy. In vitro cytotoxicity testing procedures reduces the use of laboratory animals and hence use of cultured tissues and cells have increased. The discovery and identification of new antitumor drug with low side effects on immune system has become an essential goal in many studies of immuno-pharmacology. With this aim, many medically relevant nanoparticles such as silver nanoparticles (AgNPs) were investigated for their cytotoxicity aspect. AgNPs showed different degrees of in vitro cytotoxicity [9].

This study targets synthesis of silver nanoparticles using wet chemical method, the synthesized AgNPs as antibacterial and anticancer agent is also investigated.

\section{EXPERIMENTAL}

\section{Materials}

Silver nitrate $\left(\mathrm{AgNO}_{3}, 99.99 \%\right)$, trisodium citrate dihydrate $\left(\mathrm{C}_{6} \mathrm{H}_{5} \mathrm{O}_{7} \mathrm{Na}_{3} .2 \mathrm{H}_{2} \mathrm{O}, 99.99 \%\right)$, sodium borohydride $\left(\mathrm{NaBH}_{4}, 99.99 \%\right)$, were purchased from Sigma - Aldrich, USA. Deionized water was used throughout the experiment. Gram positive and gram negative bacteria test was done in the Central lab, Women Section, King Saud University. Dimethyl sulfoxide (DMSO) and crystal violet were purchased from Sigma (St. Louis, Mo., USA). DMEM, HEPES buffer solution, L-glutamine and gentamycin were purchased from (Bio Whittaker ® Lonza, Belgium).

\section{Preparation of silver nanoparticles}

To synthesize silver nanoparticles (AgNPs), wet chemical method was used. The spherical AgNPs were prepared according to the procedure reported by Fang et al [10]. In this method, AgNPs were synthesized by using $\mathrm{NaBH}_{4}$ as reducing agent. An aqueous solution of trisodium citrate $(0.5 \mathrm{~mL}, 6 \mathrm{mM})$ was added into a flask containing $(50 \mathrm{~mL}$ of deionized water), and then, an aqueous solution of $\mathrm{AgNO}_{3}$ (1 $\mathrm{mL}, 1 \mathrm{mM}$ ) was added. Freshly prepared $\mathrm{NaBH}_{4}$ aqueous solution $(0.5 \mathrm{~mL}, 10 \mathrm{mM})$ was quickly added, and the suspension immediately turned a light yellow color. After $10 \mathrm{~s}$, the suspension changed to a darker yellow or brown color after reaction had proceeded for another 20 second.

\section{Characterization of AgNPs}

UV-visible spectroscopy analyss was carried out at a wavelength range $190-1100 \mathrm{~nm}$ in a Perkin Elmer UV-visible spectrometer Lambda 25, PerkinElmer, United Kingdom. The mean size of the silver nanoparticles was analyzed using Zetasizer, (Nano series, HT Laser, ZEN3600 from Molvern Instrument, UK), while transmission electron microscopy (TEM, JEM-1011, JEOL, Japan) was employed to determine the size, shape and morphologies of formed synthesized silver nanoparticles. Energy dispersive spectrometer (EDS) analysis was performed for the confirmation of elemental silver. Elemental analysis on single particles was carried out using Oxford Instrument, Incax-act, equipped with scanning electron microscopy (JEOL-FE SEM).

\section{Antibacterial assay}

Antimicrobial activity of nanosilver was determined using disc diffusion assay method. Pure culture of Escherichia coli, Klebsiella pneumonia (gram negative), and Staphylococcus, Bacillis subtilis (gram positive) of bacteria were used. The sterile discs were dipped in nanosilver (5, 10, $15 \mu \mathrm{g} / \mathrm{mL})$ and placed in the nutrient agar plate and kept for incubation at $37{ }^{\circ} \mathrm{C}$ for $24 \mathrm{~h}$. Upon inhibitory activity, a zone of clearing around the wells was observed. The experiments were repeated 3 times and mean values of zone diameter were determined [11]. 


\section{Evaluation of cytotoxic activity}

Colon adenocarcinoma (HCT-116) cell lines were used. The tested human carcinoma cell line was obtained from the American Type Culture Collection (ATCC, Rockville, MD).

\section{Chemicals}

\section{Staining solution}

Crystal violet stain (1\%) is composed of $0.5 \%$ $(\mathrm{w} / \mathrm{v})$ crystal violet and $50 \%$ methanol then made up to volume with distilled water and filtered through a Whatmann No. 1 filter paper.

\section{Cytotoxicity assay}

The cells were propagated in Dulbecco's modified Eagle's medium (DMEM) supplemented with $10 \%$ heat-inactivated fetal bovine serum, 1 $\%$ L-glutamine, HEPES buffer and $50 \mu \mathrm{g} / \mathrm{mL}$ gentamycin. All cells were maintained at $37^{\circ} \mathrm{C}$ in a humidified atmosphere with $5 \% \mathrm{CO}_{2}$ and were sub-cultured two times a week. Cell toxicity was monitored by determining the effect of the test samples on cell morphology and cell viability. For cytotoxicity assay, the cells were seeded in 96well plate at a cell concentration of $1 \times 10^{4}$ cells per well in $100 \mu \mathrm{L}$ of growth medium. Fresh medium containing different concentrations of the test sample was added after $24 \mathrm{~h}$ of seeding. Serial two-fold dilutions of the tested chemical compound were added to confluent cell monolayers dispensed into 96-well, flat-bottomed microtiter plates (Falcon, NJ, USA) using a multichannel pipette. The microtiter plates were incubated at $37^{\circ} \mathrm{C}$ in a humidified incubator with $5 \% \mathrm{CO}_{2}$ for a period of $48 \mathrm{~h}$. Three wells were used for each concentration of the test sample. The little percentage of DMSO present in the wells (maximal $0.1 \%$ ) was found not to affect the experiment. After incubation of the cells for $24 \mathrm{~h}$ at $37{ }^{\circ} \mathrm{C}$, various concentrations of sample $(100$, $50,25,12.5,6.25,3.125 \mu \mathrm{l} / 100 \mathrm{uL}$ ) were added, and the incubation was continued for $48 \mathrm{~h}$ and viable cells yield was determined by colorimetric method. In brief, after the end of the incubation period, media were aspirated and crystal violet solution $(1 \%, 50 \mu \mathrm{l})$ was added to each well and allowed to stand for at least $30 \mathrm{~min}$. The stain was removed and the plates were rinsed using tap water until all excess stain was removed. Glacial acetic acid (30\%, $100 \mathrm{uL})$ was then added to all the wells, mixed thoroughly, and then the absorbance of the plates was measured after gentle shaking in a microplate reader (TECAN, Inc.), using a test wavelength of 490 $\mathrm{nm}$. All the results were corrected for background absorbance detected in wells without added stain. All experiments were carried out in triplicate. The cell cytotoxic effect of each tested compound was calculated $[12,13]$.

\section{RESULTS}

After the addition of fresh $\mathrm{NaBH}_{4}$ to aqueous solution of $1 \mathrm{mM} \mathrm{AgNO}$ and $6 \mathrm{mM}$ trisodium citrate, the color changed immediately from colorless to yellowish brown in about $30 \mathrm{~s}$. Formation of AgNPs was confirmed using UVvisible spectral analysis. The UV-vis spectrum exhibited an absorption band at $392.37 \mathrm{~nm}$ (Fig. 1).

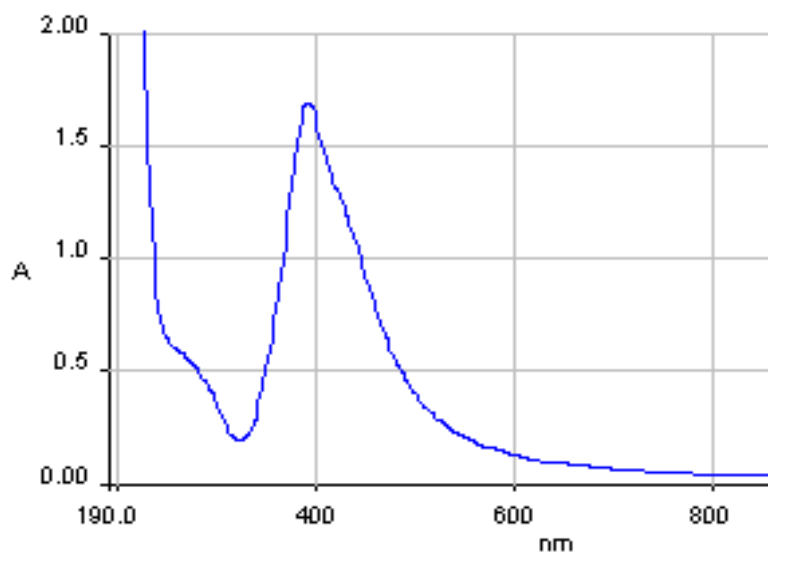

Figure 1: UV- Vis spectra of reduced $\mathrm{Ag}$ ions to AgNPs

The results of dynamic light scattering (DLS) Zetasizer showed non-homogeneous AgNPs with mean particle size of $10.31 \mathrm{~nm}$ which can be observed in the appearance in three peaks (Fig 2).

The results of transmission electron microscopy (SEM) show that the silver nanoparticles were irregular in shape with some spherical (Fig 3).

Energy dispersive $\mathrm{x}$-ray analysis (EDS) revealed strong signal in the silver region and confirms the formation of silver nanoparticles (Fig 4A). Morphological examination showed that the AgNPs agglomerated and has crystal and irregular morphology (Fig 4B).

The results of AgNPs suspension tested against different gram positive (Staphylococcus aureus, Bacillis subtilis) bacteria and gram negative (Escherichia coli, Klebsiella pneumonia) bacteria show that AgNPs exhibited high toxicity against Escherichia coli, Klebsiella and low toxicity against Staphylococcus aureus. The data are shown in Fig 5. 


\begin{tabular}{|c|c|c|c|c|c|}
\hline & & & Diam. (nm) & $\%$ Intensity & Width (nm) \\
\hline Z-Average (r.nm): & 10.31 & Peak 1: & 26.85 & 75.0 & 17.05 \\
\hline Pdl: & 0.591 & Peak 2: & 2.888 & 13.7 & 1.167 \\
\hline Intercept: & 0.786 & Peak 3: & 0.6794 & 9.1 & 0.2409 \\
\hline
\end{tabular}

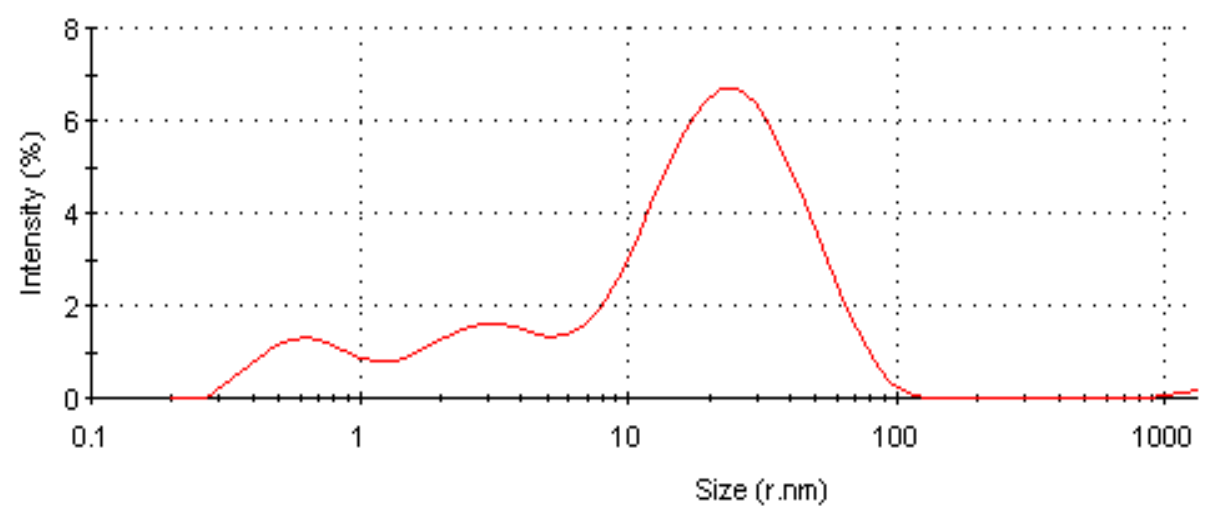

Figure 2: Size distribution of the formed AgNPs
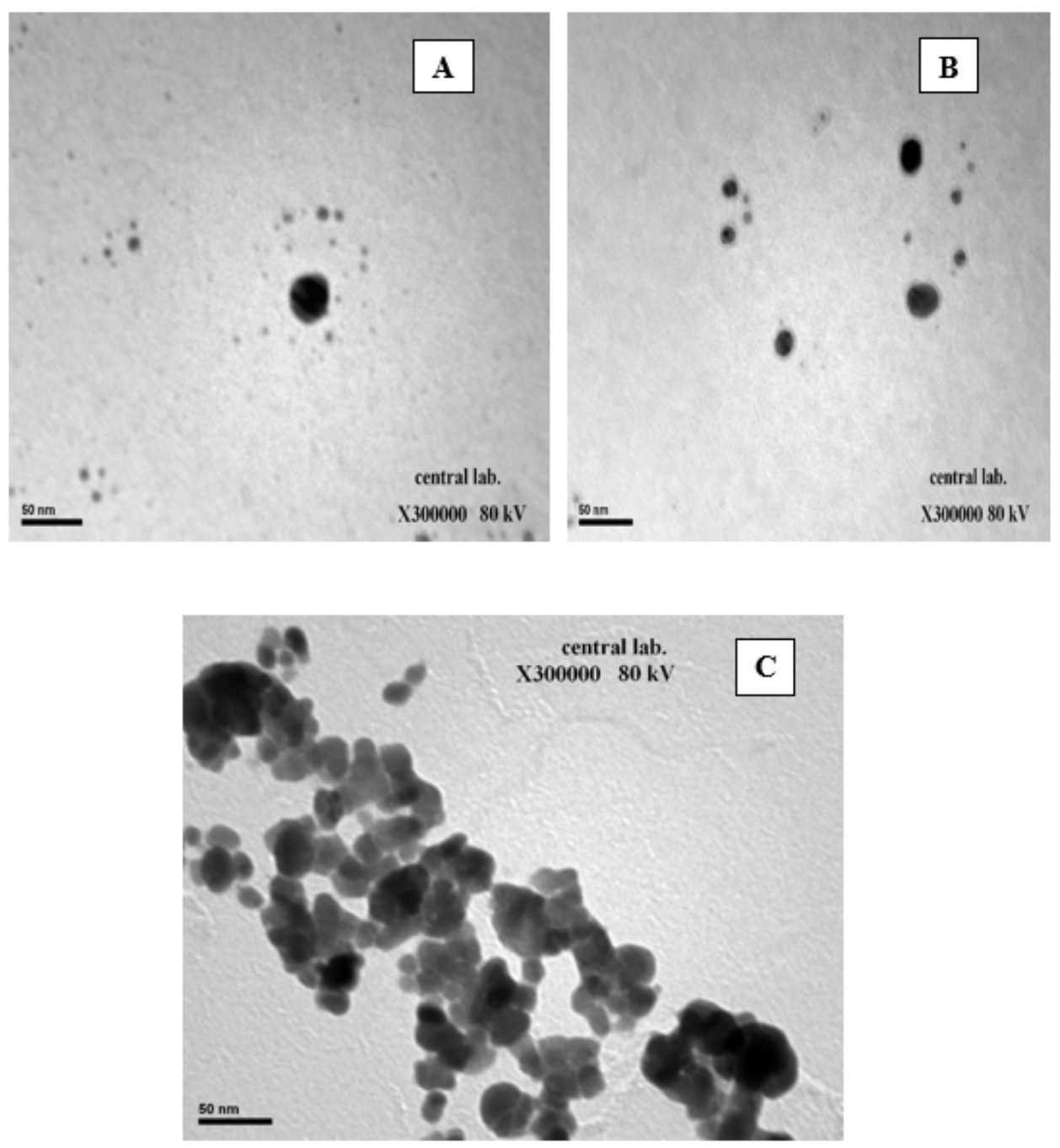

Figure 3: TEM images of the synthesized AgNPs 

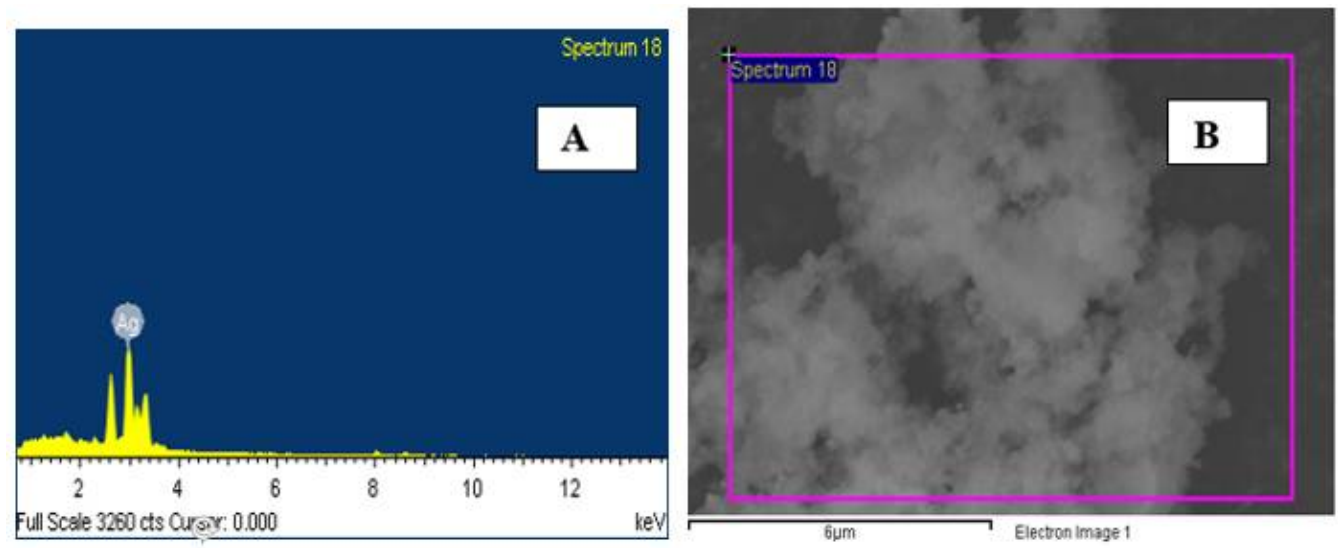

Figure 4: EDS and SEM characteristics of formed AgNPs

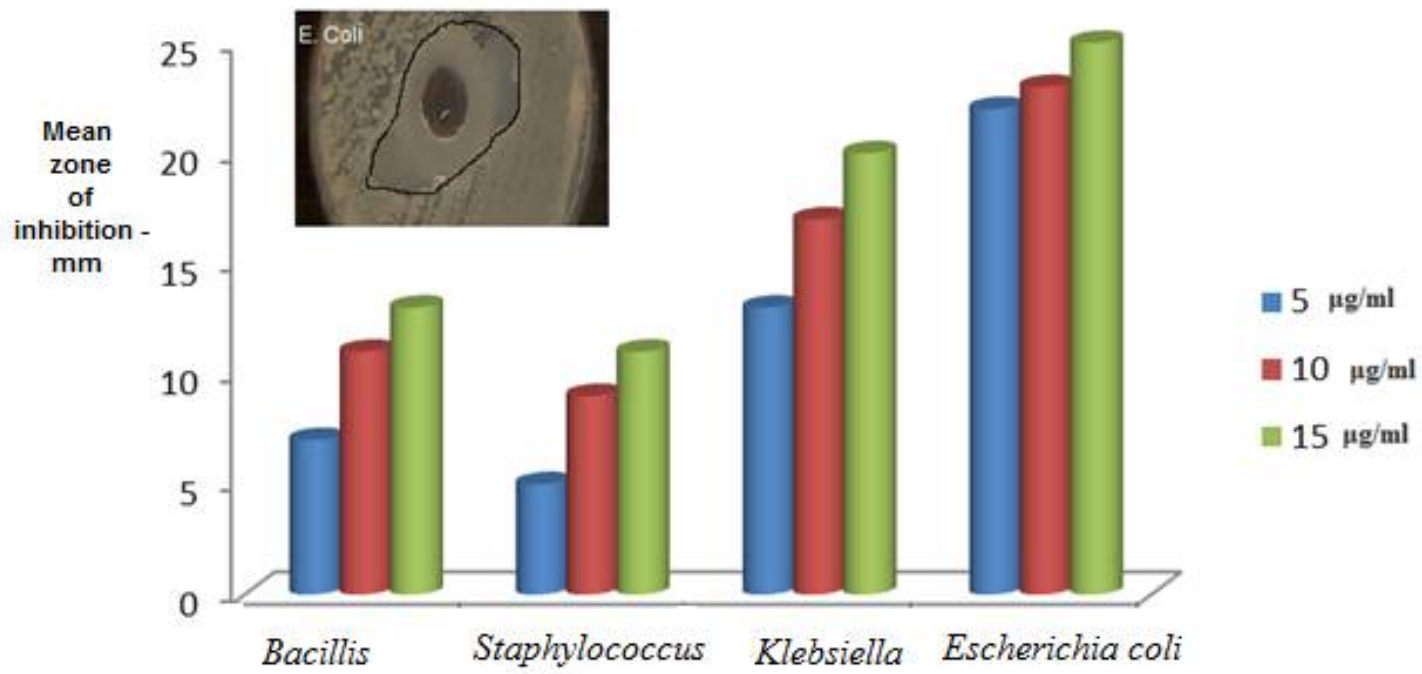

Figure 5: Diagram for the antibacterial activity assay of silver nanoparticles against microorganisms

Table 1: In vitro cytotoxicity of silver nanoparticles (AgNPs) in colon adenocarcinoma (HCT-116) cell line

\begin{tabular}{|c|c|c|c|c|}
\hline $\begin{array}{l}\text { Concentration } \\
(\mu \mathrm{l} / 100 \mathrm{uL})\end{array}$ & 1st & $\begin{array}{l}\% \\
\text { 3rd }\end{array}$ & Inhibition \% & Mean \pm S.D \\
\hline 100 & 12.94 & 13.51 & 87.44 & $12.56 \pm 1.19$ \\
\hline 50 & 19.87 & 20.84 & 80.19 & $19.81 \pm 1.06$ \\
\hline 25 & 23.52 & 25.96 & 76.06 & $23.94 \pm 1.85$ \\
\hline 12.5 & 39.56 & 36.17 & 63.3 & $36.7 \pm 2.63$ \\
\hline 6.25 & 51.27 & 45.23 & 51.87 & $48.13 \pm 3.03$ \\
\hline 3.125 & 67.82 & 63.52 & 36.42 & $63.58 \pm 4.21$ \\
\hline 0 & 100 & 100 & 0 & $100 \pm 0.0$ \\
\hline
\end{tabular}

The results obtained from MTT assay after $48 \mathrm{~h}$ of incubation indicate that that AgNPs showed significant effect on $\mathrm{HCT}-116$ with $\mathrm{IC}_{50}$ of 5.87 $\mu \mathrm{l} / 100 \mathrm{uL}$ (Table 1).

\section{DISCUSSION}

The color change from colorless to yellowish brown when $1 \mathrm{mM}$ solution of $\mathrm{AgNO}_{3}$ was added to the $6 \mathrm{mM}$ trisodium citrate was due to excitation of surface plasmon vibrations [14]. Metal nanoparticles such as silver and gold have free electrons, which gives rises to surface plasmon resonance (SPR) absorption band [15]. The UV-vis spectrum of silver nanoparticles produced by wet chemical method exhibited an absorption band at $392.37 \mathrm{~nm}$ which is a typical plasmon band, suggesting the formation of silver nanoparticles. The results of dynamic light scattering (DLS) showed non homogeneous AgNPs with average particle size of $10.31 \mathrm{~nm}$. The appearance of the three peaks in Fig 2 shows the polydispersity of nanoparticles which indicates that the nanoparticles may not be stable over a long storage period, and also that 
there are different sizes of the AgNPs in the suspension of the nanoparticles. TEM images recorded at high magnification morphology of the synthesized silver nanoparticles indicates that some of nanoparticles were spherical in shape with a smooth surface morphology while other were aggregated and irregular shaped. These results were suitable with the zetasizer results and UV-visible spectroscopic analysis. The energy dispersive $\mathrm{X}$-ray analysis (EDS) revealed strong signal in the silver region and confirms the formation of silver nanoparticles, which illustrates that optical absorption peak was observed approximately at $3 \mathrm{keV}$, This is typical for the absorption of metallic silver nanostructure due to surface plasmon resonance (Morones et al, 2005). The morphology were carried out on the FE-SEM images showed the silver nanoparticles were agglomerated and has crystal line and irregular morphology, these result agreed with TEM results.

The effect of silver nanoparticle was more in Gram negative bacteria than Gram positive. This could be due to the fact that the relative abundance of negative charges on Gram negative bacteria assists the interaction between the nanoparticles and the cell wall [16]. Furthermore, the antibacterial properties shown above, allows us to confirm that our results are similar to those of Morones et al [17] who reported that small size nanoparticles may pass through cell membranes generating cell malfunction. Also, Choia et al has reported that the positive charge on the $\mathrm{Ag}$ ion is crucial for its antimicrobial activity through the electrostatic attraction between negative charged cell membrane of microorganism and positive charged nanoparticles [18].

Silver is a soft acid, and there is a natural tendency of an acid to react with a base, in this case, a soft acid to react with a soft base. The cells are majorly made up of sulfur and phosphorus which are soft bases. The action of these nanoparticles on the cell can cause the reaction to take place and subsequently lead to cell death [19].

The cytotoxic effects of AgNPs may probably due to the fact that AgNPs may interfere with the proper functioning of cellular proteins and induce subsequent changes in cellular chemistry [20]. Zolghadri et al demonstrated that AgNPs provide a relatively high hydrophobicity inside bovine hemoglobin which causes a transition from alpha helixes to beta sheets and leads to partial unfolding and aggregation of the protein [21], other researchers suggest that AgNPs are likely to interact with thiol rich enzymes [22]; Therefore, it is possible that once penetrated into cells, AgNPs may attack functional proteins of cells which results in partial unfolding and aggregation of proteins as it is the case in the bovine hemoglobin.

\section{CONCLUSION}

Silver nanoparticles have successfully been synthesized from silver nitrate and sodium borohydride $\left(\mathrm{NaBH}_{4}\right)$ as reducing agent by wet chemical method. The silver nanoparticles exhibit broad size distribution and morphology with mean size $10.31 \mathrm{~nm}$. The silver nanoparticles exhibit cytotoxic and broad antibacterial activities against different strains of bacteria making them applicable to various antibacterial control systems. Thus, the AgNPs synthesized by wet chemical method are a promising candidate for use in nanomedicine.

\section{ACKNOWLEDGEMENT}

The authors extend their appreciation to the Deanship of Scientific Research at King Saud University for funding this work through research group no. RGP- VPP-278.

\section{REFERENCES}

1. Vaidyanathan $R$, Kalishwaralal $K$, Gopalram $S$, Gurunathan S. Nanosilver: the burgeoning therapeutic molecule and its green synthesis. Biotechnol Adv 2009; 27: 924-937.

2. Kumar V, Yadav SK. Plant-mediated synthesis of silver and gold nanoparticles and their applications. J Chem Technol Biotechnol 2009; 84: 151-157.

3. Mallick K, Witcomb MJ, Scurrell MS. Polymer stabilized silver nanoparticles: a photochemical synthesis route. Mater Sci J 2004; 39: 4459-4463.

4. Khan Z, Al-Thabaiti SA, Obaid AY, Al-Youbi AO. Preparation and characterization of silver nanoparticles by chemical reduction method. Colloid Surf $B$ biointerfaces 2011; 82: 513-517.

5. Sahoo PK, Kalyan Kamal SS, Jagadeesh Kumar T, Sreedhar B, Singh AK, Srivastava SK. Synthesis of Silver Nanoparticles using Facile Wet Chemical Route. Defence Science Journal 2009; 59: 447-455.

6. Hussain JI, Kumar S, Hashmi AA, Khan Z. Silver nanoparticles: reparation, characterization, and kinetics. Adv Mat Lett 2011; 2(3): 188-194.

7. Chen $X$, Schluesener HJ. Nanosilver: a nanoproduct in medical application. Toxicol Lett 2008; 176: 1-12.

8. Gangadharan $D$, Harshvardan $K$, Gnanasekar G, Dixit $D$, Popat KM, Anand PS. Polymeric microspheres containing silver nanoparticles as a bactericidal agent for water disinfection. Water Res 2010; 44: 5481-5487. 
9. Saraniya Devi J, Valentin Bhimba B, Krupa Ratnam, In vitro anticancer activity of silver nanoparticles synthesized using the extract of Gelidiella Sp. International Journal of Pharmacy and Pharmaceutical Sciences 2012; 4: 0975-1491.

10. Fang J, Zhong C, Mu R. The study of deposited silver particulate films by simple method for efficient SERS. Chemical Physics Letters 2005; 401: 271-275.

11. Jeong SH, Yeo SY, Yi SC. The effect of filler particle size on the antibacterial properties of compounded polymer/silver fibers. J Mat Sci 2005; 40: 5407- 411.

12. Mosmann T, Immunol T. Methods, Rapid colorimetric assay for cellular growth and survival: application to proliferation and cytotoxicity assays 1983; 65, 55.

13. Rai A, Singh A, Ahmad A, Sastry M. Role of halide ions and temperature on the morphology of biologically synthesized gold nanotriangles. Langmuir 2006; 22 736-741.

14. Vijayan $P$, Raghu $C$, Ashok $G$, Dhanaraj $S$ A, Suresh $B$. Antiviral activity of medicinal plants of Nilgiris. Indian $\mathrm{J}$ Med Res 2004; 120, 24.

15. Noginov MA, Zhu G, Bahoura M, Adegoke J, Small C, Ritzo BA, Drachev VP, Shalaev VM. The effect of gain and absorption on surface plasmons in metal nanoparticles. Applied Physics B 2007; 86:455-460.

16. Sadeghi B, Jamali M, Kia S, Amininia A, Ghafari $S$. Synthesis and characterization of silver nanoparticles for antibacterial activity. Int J Nano Dim 2010; 1(2): 119124.

17. Morones JR, Elechiguerra JL, Camacho A, Holt K, Kouri JB, Ramírez JT, Yacaman MJ. The bactericidal effect of silver nanoparticles. Nanotechnology 2005; 16: 2346.

18. Choia O, Kanjun Dengb K, Kimc Nam J. The inhibitory effects of silver nanoparticles, silver ions, and silver chloride colloids on microbial growth. Water Res 2008; 42: 3066-74.

19. Sukumaran Prabhu, Eldho $K$ Poulose. Silver nanoparticles: mechanism of antimicrobial action, synthesis, medical applications, and toxicity effects. International Nano Letters 2012; 2:32

20. Rogers JV, Parkinson CV, Choi YW, Speshock JL, Hussain SM. A preliminary assessment of silver nanoparticle inhibition of monkeypox virus plaque formation. Nanoscale Research Letters 2008; 3; 129133

21. Zolghadri S, Saboury A, Golestani A, Divsalar A, RezaeiZarchi S, Moosavi-Movahedi A. Interaction between silver nanoparticle and bovine hemoglobin at different temperatures. Journal of Nanoparticle Research 2009; 11, 1751-1758.

22. Jose Ruben Morones, Jose Luis Elechiguerra1, Alejandra Camacho, Katherine Holt, Juan B Kouri, Jose Tapia Ramírez and Miguel Jose Yacaman. The bactericidal effect of silver nanoparticles. Nanotechnology 2005; 16 : 2346-53. 